\title{
Kurak ekolojik koşullar altında oluşmuş toprakların detaylı toprak etüt haritalama çalışması ve sınıflaması*
}

\section{Tülay TUNÇAY ${ }^{1}$}

1Toprak Gübre ve Su Kaynakları Merkez Araştırma Enstitüsü, Ankara

*Bu çalışma TÜBİTAK tarafından desteklenmiştir (Proje No TOVAG 1100 729).

Alınış tarihi: 9 Aralık 2018, Kabul tarihi: 29 Mart 2019

Sorumlu yazar: Tülay, TUNÇAY, e-posta: tulaytuncay@gmail.com

\section{$\ddot{0} \mathbf{z}$}

Araştırmanın amacı, kurak ekosistem koşulları altında oluşmuş toprakların seri düzeyinde detaylı toprak etüd ve haritalama çalışmasını yapmak ve elde edilen sonuçlar ile Eski Amerika Sinıflama Sistemine göre yapılmış toprak haritası ile karşılaştırılmasıdır. Konya İli Kadınhanı İlçesinde yer alan araştırma alanı, 421239-3535249 doğu ve 488389-4272469 kuzey enlemleri (Zone 36, UTMmetre) arasında uzanan Altınova Tarım İşletmesi arazisi içerisinde seçilen $8 * 8\left(64 \mathrm{~km}^{2}\right)$ bir alandır ve deniz seviyesinden yüksekliği 915 m'dir. Uzun yıllar yıllık ortalama yağışı $302.8 \mathrm{~mm}$ ve sıcaklık ise $12.8^{\circ} \mathrm{C}$ dir. Araştırma alanının toprak nem rejimi aridic ve toprak sıcaklık rejimi mesic olarak belirlenmiștir. Araștırma alanına ait eski büyük toprak grubu düzeyinde olan sayısal toprak haritası, topoğrafik haritası, uydu görüntüsü ve sayısal yükseklik modeli kullanılarak, araştırma alanı içerisinde 10 profil tanımlanarak, horizon esasına göre toprak örnekleri alınmıştır. Alınan toprak örneklerinin laboratuvarda yapılan fiziksel ve kimyasal analiz sonuçları ile arazi çalışmalarından elde edilen verilerin değerlendirilmesi sonucu, toprak taksonomisi alt gurup düzeyinde beş adet ve WRB sınıflandırma sistemine göre ise üç alt gurupta toprak sinıfı belirlenmiştir. Marn, kalker ve kireçtaşı üzerinde oluşan toprak profilleri toprak taksonomisine göre petrocalcid, calcid ve cambic genetik horizonları içeren toprakların büyük bir çoğunluğu Aridisol olarak sinıflandırılırken, Saçıkara serisi Vertisol olarak sınıflandırılmıştır. Araştırma alanı toprakları WRB sinıflandırma sistemine göre ise, Cambisol,
Calcisol ve Vertisol olarak sınıflandırılmıştır. Ayrıca, araştırma alanına ait Büyük Toprak Gruplarının içeren toprak haritasındaki bazı faz özellikleri (eğim, derinlik vs.) ile elde edilen detaylı toprak haritası karşlaştırılmıştır.

Anahtar kelimeler: Kurak ekosistem, toprak etüt ve haritalama, toprak sinıflaması

\section{Classification and soil survey and mapping of the soils formed under arid ecological condition}

\begin{abstract}
The aim of the research is to make detailed soil survey and mapping studies at the serial level of the soils under arid ecosystem conditions and to compare the results with the soil map made according to the Old American Classification System. The research area is located in Kadınhanı district of Konya province. The research area, the district of Kadınhanı in Konya province, located between 421239-3535249 east and 488389-4272469 m north (Zone 36, UTM- meters), is an area of $8 * 8$ (64 $\mathrm{km}^{2}$ ) within the Altınova State Farm soils, and its altitude above sea level is $915 \mathrm{~m}$. Long term annual average precipitation and temperature are 302.8 $\mathrm{mm}$ and $12.8{ }^{\circ} \mathrm{C}$. Soil moisture regime is aridic and soil temperature regime is mesic. Used old great soil groups map, topographic map, digital elevation model of the research area, 10 profiles were identified in the research area and soil samples were taken according to horizon basis. According to the results of physical and chemical analysis of the soil
\end{abstract}


samples taken from the laboratory and the data obtained from field studies, five different sub-groups were determined according to Soil Taxonomy, and were determined three sub-groups according to WRB system. While the majority of soil profiles formed of marn, limestone and limestone are classified as Aridisol, including petrocalcid, calcid and cambic genetic horizons according to soil taxonomy, the Saçlkara series is classified as Vertisol. According to the WRB classification system, the research area is classified as Cambisol, Calcisol and Vertisol. In addition, some phase properties (slope, depth, etc.) in the soil map containing the Great Soil Groups belonging to the research area was compared with obtained detailed soil map.

Key words: Arid ecosystem, soil survey and mapping, soil classification

\section{Giriş}

Ülkelerin ekonomik gelişmesi doğal kaynaklarının zenginliğine ve bu kaynakların etkin ve sürdürülebilir biçimde kullanılmasına bağlıdır. Sürdürülebilir kalkınma, doğal kaynaklardan bilimsel yöntemlerle ve güncel olarak elde edilen bilgilerin doğru bir şekilde kullanımı ile sağlanabilir. Son derece sinırlı, yenilenemeyen ve üretilip çoğaltılamayan toprak ve su kaynaklarımız, yanlış arazi kullanımları, erozyon ve diğer arazi bozunumları sonucu hızlı bir şekilde tahrip edilip yok olmakta ve bu süreç hızla devam etmektedir. Toprak ve su kaynakları; ulusal ölçekte planlanması ve havza - alt havza bazında projelendirilmesi gereken doğal kaynaklardır. Bu nedenle, bütünsel havza yönetimi doğal kaynaklarla birlikte havzada yaşayan halkın sosyo-ekonomik yapısını, havzanın hidrolojik özelliklerini, iklim, toprak ve bitki varlığını ortaya koymayı gerektirmektedir (Dengiz ve ark., 2015; Coşkun ve Dengiz, 2016 ). Topraklarımızın amacına uygun sürdürülebilir kullanımlarının belirlenmesi ve planlanması, topraklar hakkında detaylı, güncel ve doğru bilgilerin elde edilmesiyle sağlanabilir. Ülkemizde topraklar hakkında ayrıntılı ve güncel bilgileri içeren detaylı toprak etüt ve haritalarının bulunmayışı en önemli sorunların başında gelmektedir (Bayramin ve ark., 2013).

Ülkemizde toprak sınıflandırma toprak etüd ve haritalama çalışmaları ilk defa 1951 yılında Tarım Bakanlığı bünyesindeki "Toprak Muhafaza ve Zirai Sulama Teşkilatı" ile başlamış ve Çağlar (1958) tarafından toprakların morfolojik özellikleri dikkate alınarak olușturulan Türkiye Toprak Haritası'nda 11 farklı toprak grubu yer almış, Türkiye topraklarını belli başlı iklim bölgelerine ayırarak incelemiştir (Dengiz ve ark., 2010). A.B.D. toprak uzmanı Oakes (1958), 1952-1954 yılları arasında yaptığı arazi çalışmaları sonucunda 1938 Amerikan Toprak Sinıflandırma Sistemi'ndeki büyük toprak gruplarının yanı sıra eğim, taşlılık, drenaj ve tuzluluk gibi toprak fazlarını da esas alarak 1:800.000 ölçekli Türkiye Umumi Toprak Haritası'nı hazırlamıştır (Dengiz ve Bayramin, 2003). Toprak-su Genel Müdürlüğü tarafından 1966-1971 yılları arasında Türkiye Geliştirilmiş Toprak Haritası (TGTH) etüdleri çalışması ile tüm ülke toprakları 1/25K ölçekli topoğrafik haritalar kullanılarak istikşafi düzeyde incelenerek haritalanmıştır. Bu çalışmada haritalama ünitesi olarak 1938 Amerikan sinıflama sisteminin büyük grupları ile arazi gözlemleriyle saptanan bunların önemli fazları derinlik, eğim, taşlılık, aşınım derecesi ve benzer özellikler haritalara işlenmiştir. Elde edilen veriler değerlendirilerek her bir il için $1 / 100 \mathrm{~K}$ ölçekli Toprak Kaynağı Envanter Haritası ve Raporu, ayrıca ülkemizde mevcut 26 Büyük Su Toplama Havzası için 1/200K ölçekli Havza Toprak Haritası ve Raporu şeklinde yayınlanmıştır. Etüt istikşafi düzeyde olduğundan $1 / 25 \mathrm{~K}$ ölçeğin elverdiği bütün ayrıntılara inilememiştir. Ülke topraklarının ilk kez orijinal arazi etüdleri ile geniş anlamda incelenerek haritalandığı çalışmada aynı zamanda toprakların önemli sorunları ve bunların dağılım alanları da ortaya konmuştur. Bu haritaların en önemli eksikliği, sınırların yoklama yöntemi ile kabaca belirlenmiş olması ve toprak serilerini göstermemesi diğer bir deyişle toprakların morfolojik, fiziksel ve kimyasal özelliklere ilişkin verilerden yoksun olmasıdır (Başayiğit ve ark., 2008). Bu özelliği ile yoklama toprak haritaları, büyük ölçekli arazi kullanım planlarının yapılması için uygun değildir ve yetersiz kalmaktadır. Buna karşılık, 1950'li yıllarda Amerika Birleşik Devletlerinde detaylı toprak etüt ve haritalama çalışmaları hemen hemen tamamlanmış, 16.000 adet toprak serisi tanımlanarak haritalanmış ve oluşturulan toprak haritaları foto mozaikler altlık kullanılarak basılmıştır (Şenol ve ark., 2010). Son yıllarda bilgisayar teknolojisindeki hızlı yeniliklere paralel olarak Çullu (2012) uzaktan algılama, coğrafi bilgi sistemi, jeoistatistik yöntemler ile modelleme tekniklerinin toprak özelliklerinin incelenmesi ve haritalanması çalışmalarında kullanılmaya başlanması detaylı toprak etüt çalışmalarının önemini daha da artırmış olduğunu bildirmiş ve bu konuda birçok çalışmalar yapılmış ve yapılmaya 
devam etmektedir (Dengiz, 2007; Erkoçak ve ark., 2010; Dengiz ve Başkan, 2010). Akbaș ve Yıldız (2004), daha önceden detaylı temel toprak haritası hazırlanmış bir arazide seçilen test alanında, yüzey toprağının bazı özelliklerindeki değişimini jeoistatistiksel teknikler kullanarak haritalanmasını amaçlamışlardır. Detaylı temel toprak haritasındaki sınırlar ile kriging yöntemi ile elde edilen değişim haritası ile çakıştırmışlardır. Haritalanan özeliklerin, temel toprak haritası ile benzerlikleri ve bu haritalama tekniğinin ve toprak haritalarının CBS çalıșmalarındaki kullanım etkinliğinin tartıșılmıș ve buna ilaveten toprak haritası hazırlanmamış bölgelerde jeoistatistik yöntemlerle istenilen toprak değişkenine ait haritalar üretilebileceği bildirilmiştir (Başkan ve ark., 2009; Tunçay ve ark., 2018).

Toprak haritaları, arazi kaynaklarının doğru ve sürdürülebilir kullanımını sağlayan en önemli veri kaynağıdır. Detaylı toprak etüt ve haritalama çalışmaları sonucu üretilen toprak haritaları ve bununla ilişkili sunulan raporlar kullanıcılar için toprak veri tabanını oluşturmaktadır. Yöresel, bölgesel ve ulusal planlamalara geçmeden önce toprak kaynaklarının niteliksel ve niceliksel olarak incelenmesi, eldeki kaynakların potansiyellerinin saptanması, gelişen teknolojilere paralel olarak veri tabanlarının ve haritalarının oluşturulması gerekmektedir (Kursun ve Dengiz, 2018). Uluslararası ölçekte ise nüfus artışı ve gıda taleplerinin artması nedeniyle toprak kaynaklarına baskının artmasıyla birlikte 2012 yılında FAO (Birleşmiş Milletler Gıda ve Tarım Örgütü) GSP (Global Soil Partnership), küresel toprak paydaşlığını kurmuştur. $\mathrm{Bu}$ paydaşlığın amacl, sürdürülebilir kalkınma hedefleriyle sürdürülebilir kalkınmayı benimseme firsatlarını araştıran karar vericilerin, politika yapıcıların bölgesel karar verme sürecini kolaylaştırmayı hedeflemektedir. Paydaşlık kapsamında üye ülkelerde toprak veri tabanı hazırlama veya güncelleme çalışmaları yapılması ve bu yönde kapasite geliştirme projeleri yürütülmektedir. Ülkesel ölçekte gerek tarımsal, gerekse tarım dışı uygulamaların doğru ve planlı bir şekilde yapılabilmesi için toprak veri tabanının varlığına ve güncellenmesine bağlıdır.

$\mathrm{Bu}$ çalışmanın amacı, Altınova Devlet Üretim çiftlik arazileri içerisinde belirlenen pilot alanda, semi-arid ekosistem koșulları altında oluşmuş toprakların seri düzeyinde detaylı toprak etüt ve haritalama çalışmasını yapmak ve elde edilen sonuçlar ile 1980'li yıllarda 1938 Eski Amerika Sinıflama
Sistemine göre yapılmış toprak haritası ile karşılaştırmanın yapılmasını kapsamaktadır.

\section{Materyal}

\section{Çalışma alanının yeri}

$\mathrm{Bu}$ çalışma, Tarım İşletmeleri Genel Müdürlüğü'ne ait Altınova Tarım İşletmesi'nde $8 * 8$ km²'lik bir alan içerisinde yürütülmüştür. İç Anadolu Bölgesinin 421239-3535249 Doğu ve 488389-4272469 Kuzey enlemleri (Zone 36, UTM-metre) arasında yer alan, ortalama deniz seviyesinden 915 m rakıma sahip Altınova TİGEM arazileri, Konya iline bağlı Kadınhanı ilçesinin 60 km kuzeyinde, Ankara'ya 189 km ve Konya iline $126 \mathrm{~km}$ uzaklıktadır (Şekil 1). Kültür altındaki alanlarda buğday, arpa, tritikale, yonca, mısır gibi ürünler yetiştirilmektedir. Bunlar arasında buğday en fazla yetiştirilen üründür (http://www.tigem.gov.tr/). İşletmede nadas ekim sistemi uygulanmaktadır.

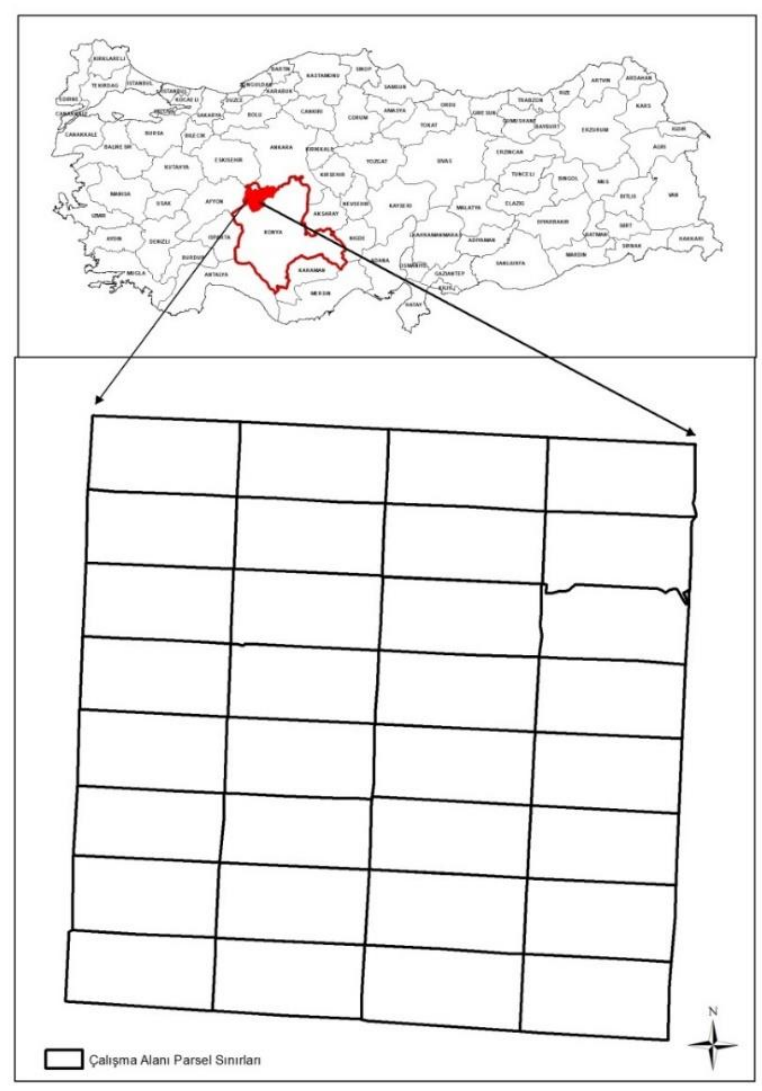

Şekil 1. Araştırma alanının lokasyon ve parsel desen haritası

Altınova Tarım İşletmeleri Genel Müdürlüğü içerinde meteoroloji istasyonu bulunmaktadır. Altınova Tarım İşletmesine ait 1999-2011 yılları arasındaki meteorolojik verilerinden elde edilen toprak-su bütçesi diyagramı Çizelge 1'de verilmiştir. Yıllık ortalama toprak sıcaklığının $8{ }^{\circ} \mathrm{C}$ 'den fazla, fakat 15 
${ }^{\circ} C^{\prime}$ den daha az ve ortalama yaz sıcaklığı (Haziran, Temmuz, Ağustos) ile ortalama kış sıcaklığı (Aralık, Ocak, Şubat) arasındaki fark $5{ }^{\circ} \mathrm{C}$ 'den daha fazla olması nedeniyle araştırma alanı toprakları sıcaklık rejimi Mesic'tir. Ayrica toprak taksonomisine (Soil Survey Staff, 1999) göre ise toprağın ardışık 90 günden fazla (5 ay) kuru kalması nedeniyle araştırma alanı Aridik nem rejimine dahil edilmiştir. $\mathrm{Bu}$ durum Kurşun ve Dengiz (2018) tarafindan Konya Karapınar da yaptıkları çalışmada, toprak nem ve sıcaklık rejimini Newhall modeline göre benzer sonucu belirlemişlerdir.

Çizelge 1. Araştırma alanına ait toprak - su bütçesi

\begin{tabular}{|c|c|c|c|c|c|c|c|c|c|c|c|c|c|}
\hline & 0 & Ş & $\mathrm{M}$ & $\mathrm{N}$ & $\mathrm{M}$ & $\mathrm{H}$ & $\mathrm{T}$ & $\mathrm{A}$ & $\mathrm{E}$ & $\mathrm{E}$ & $\mathrm{K}$ & $\mathrm{A}$ & Yıllık \\
\hline $\mathrm{T}^{\circ} \mathrm{C}$ & 1.5 & 2.7 & 8.1 & 11.3 & 16.2 & 19.8 & 23.7 & 24.7 & 19.6 & 14.3 & 8.1 & 3.3 & 12.8 \\
\hline I & 0.2 & 0.4 & 2.0 & 3.4 & 5.9 & 8.0 & 10.5 & 11.2 & 7.9 & 4.9 & 2.08 & 0.5 & 57.2 \\
\hline $\mathrm{P}$ & 26.7 & 25.5 & 33.4 & 41.9 & 33.3 & 27.5 & 7.1 & 10.8 & 14.2 & 20.7 & 30.6 & 30.6 & 302.3 \\
\hline UPE & 1.3 & 3.8 & 30.8 & 57.9 & 114.7 & 167.9 & 236.1 & 255.3 & 164.7 & 90.6 & 30.8 & 5.6 & \\
\hline PE & 0.2 & 3.3 & 31.7 & 62.5 & 135.3 & 198.1 & 283.3 & 291 & 169.6 & 88.8 & 27.4 & 4.9 & \\
\hline P-PE & 26.5 & 22.2 & 1.7 & -20.6 & -102 & -171 & -276.2 & -280.2 & -155 & -68.1 & 3.2 & 25.7 & \\
\hline W & 55.4 & 77.6 & 79.3 & 58.7 & 0 & 0 & 0 & 0 & 0 & 0 & 3.2 & 28.9 & \\
\hline $\mathrm{U}$ & & & & 20.6 & 58.7 & & & & & & & & 79.3 \\
\hline D & & & & & 41.3 & 100 & 100 & 100 & 100 & 100 & & & \\
\hline $\mathrm{R}$ & 26.5 & 22.2 & 1.7 & & & & & & & & 3.2 & 25.7 & \\
\hline
\end{tabular}

T: Sıcaklık, İ:Sıcaklık indisi, P: Yağış, UPE: Düzeltilmiş evapotransprasyon, W: Kullanım, PE: Evapotransprasyon U: Kullanılan su, D: Noksanlık, R: Depolama, S:Fazlalık

\section{Yöntem}

Çalışmada öncelikle eski büyük toprak gurubu düzeyinde olan sayısal toprak haritaları, parselasyon haritaları, uydu görüntüleri ve 1:25.000 ölçekli topoğrafik haritalar ilişkilendirilerek, koordinat uyumsuzlukları giderilmeye çalışılmış ve uyumsuzluk oranları minimum seviyeye indirilmiștir. Koordinatlandırma işlemlerini takip eden süreç içerisinde, öncelikle öznitelik bilgileri, sayısal yükselti modeli ile birlikte CBS ile analiz edilmiștir. Analiz sonrasında çalıșma alanı içerisinde 10 farklı taslak serinin dağılım gösterdiği belirlenmiştir. $\mathrm{Bu}$ serilere ait temsili profil çukur yerleri belirlendikten sonra 12 toprak profili açılmış ve 10 farklı toprak serisine ait profili tanımlanmış ve bu profillerden genetik horizon esasına göre 40 toprak horizonu örneklenmiştir. Arazide toprakların morfolojik özelliklerinin incelenmesi amaciyla dikkate alınacak kriterler, örneklemeler ve sinıflandırma için Soil Survey Staff (1993 ve 1999) kullanılmıştır. Alınan toprak örneklerinde bünye Bouyoucous (1951), hacim ağırlığı Blake ve Hartge (1986), hidrolik iletkenlik Klute ve Dirksen (1986), pH (1:2'lik toprak-su karışımında, Hendershot ve ark., (1993), EC (1:2'lik toprak-su karıșımında), Jackson (1958), organik madde Jackson (1958), kireç analizi Çağlar (1958), katyon değișim kapasitesi analizi Rhoades (1982), değișebilir katyonlar Thomas (1986), saturasyon yüzdesi Tüzüner (1990) yöntemlerine göre belirlenmiştir. Daha sonrasında, farklı özelliklere sahip toprakların analiz sonuçları dikkate alınarak gerekli düzeltmeler yapılmış ve arazi sınırları kesinleştirilerek çalışma alanına ait temel toprak haritası yapılmıştır (Şekil 2). Ayrıca, araștırma alanının 1980'li yıllarda 1938 Eski Amerika Sınıflama Sistemine göre yapılmış Büyük Toprak Gruplarını içeren toprak haritasındaki bazı faz özellikleri (eğim, derinlik vb) ile elde edilen toprak haritası karşılaștırılmıştır.

\section{Bulgular ve Tartışma}

\section{Toprak serilerinin bazı fiziksel ve kimyasal özellikleri}

Çalışma alanında toplam 10 seri belirlenmiştir (Şekil 2). Bu serilerden Killar Serisi yan dere aluviyalleri üzerinde oluşmuş toprak olup diğer seriler ise neojen göl terasları üzerinde oluşmuş topraklardır. Çalışma alanına ait serilerin bazı fiziksel ve kimyasal analiz sonuçları Çizelge 2 ve Çizelge 3'de verilmiştir. Serilere ait dağılım oranları ise Çizelge 4 ve Şekil 2'de verilmiştir. Şekil 2'den de görüleceği gibi, araştırma alanı içerisinde Odabaşı serisi 1716.6 ha (\%26.5), Altınova serisi 1020.3 ha (\%15.8) ve Kap serisi 807.4 ha $(\% 12.5)$ bir alanı kaplayarak hakim toprak serileri olarak yer almıştır.

Odabaşı serisi, neojen eski göl terası üzerinde gelişen bu topraklar araştırma alanının güney ve kuzey kesimlerinde bulunmakta ve araștırma alanının \%26.5'ini oluşturmaktadır. Marn-kalker ana materyali üzerinde oluşmuş sığ/orta derinlikli profile sahip topraklardır. 
Çizelge 2. Altınova TİGEM araştırma alanı toprak profilleri kimyasal analiz sonuçları

\begin{tabular}{|c|c|c|c|c|c|c|c|c|c|}
\hline \multirow{2}{*}{ Horizon } & \multirow{2}{*}{$\begin{array}{c}\text { Derinlik } \\
\text { cm }\end{array}$} & \multirow{2}{*}{$\mathrm{pH}$} & \multirow{2}{*}{$\begin{array}{c}\text { EC } \\
\text { dS.m-1 }\end{array}$} & \multirow{2}{*}{$\begin{array}{c}\text { Kireç } \\
\%\end{array}$} & \multirow{2}{*}{$\begin{array}{c}\mathrm{OM} \\
\%\end{array}$} & \multirow{2}{*}{$\begin{array}{c}\text { KDK } \\
\text { cmol. kg-1 }\end{array}$} & \multicolumn{3}{|c|}{ Değișebilir Katyonlar, cmol kg-1 } \\
\hline & & & & & & & $\mathrm{Na}^{+}$ & $\mathrm{K}^{+}$ & $\mathrm{Ca}^{++}+\mathrm{Mg}^{++}$ \\
\hline \multicolumn{10}{|c|}{ Altınova Serisi } \\
\hline Ap & $0-21$ & 8.1 & 0.4 & 12.4 & 1.2 & 42.8 & 0.6 & 1.7 & 40.3 \\
\hline Bw1 & $21-45$ & 8.1 & 0.4 & 31.5 & 1.1 & 39.6 & 0.6 & 0.5 & 38.2 \\
\hline Bw2 & $45-72$ & 7.8 & 0.4 & 41.5 & 1.1 & 32.6 & 0.7 & 0.7 & 31.2 \\
\hline $\mathrm{Ck}$ & $72-107$ & 7.9 & 0.5 & 57.7 & 1.0 & 24.9 & 0.7 & 0.5 & 23.3 \\
\hline $\mathrm{C} 2$ & $107-152$ & 8.0 & 1.2 & 41.4 & 0.7 & 14.3 & 1.4 & 0.4 & 13.7 \\
\hline \multicolumn{10}{|c|}{ Hacıfakılı Serisi } \\
\hline Ap & $0-21$ & 8.19 & 0.42 & 5.6 & 1.8 & 56.0 & 0.7 & 2.6 & 52.4 \\
\hline A2 & $21-40$ & 8.02 & 0.34 & 7.1 & 1.7 & 52.4 & 1.0 & 1.5 & 49.9 \\
\hline A3 & $40-63$ & 8.01 & 0.34 & 17.2 & 1.0 & 50.5 & 0.8 & 1.1 & 48.4 \\
\hline Bw1 & $63-82$ & 7.99 & 0.29 & 23.2 & 0.6 & 46.4 & 0.7 & 1.0 & 44.3 \\
\hline Bw2 & $82-100$ & 7.94 & 0.27 & 31.0 & 0.5 & 47.1 & 0.7 & 0.9 & 45.2 \\
\hline $\mathrm{C}$ & $100-125$ & - & - & - & - & - & - & - & - \\
\hline \multicolumn{10}{|c|}{ Çatalca Serisi } \\
\hline Ap & $0-18$ & 8.28 & 0.445 & 8.7 & 1.5 & 51.3 & 0.7 & 2.4 & 48.0 \\
\hline $\mathrm{A} 2$ & $18-55$ & 7.98 & 0.344 & 3.0 & 1.1 & 52.1 & 0.7 & 1.6 & 49.5 \\
\hline Bw & $55-74$ & 7.96 & 0.279 & 1.0 & 1.0 & 48.4 & 1.0 & 1.5 & 45.6 \\
\hline $\mathrm{BCk}$ & $74-92$ & 8.07 & 0.270 & 3.7 & 0.9 & 38.6 & 0.7 & 1.1 & 35.2 \\
\hline $\mathrm{Ck}$ & $92-115$ & 8.0 & 0.318 & 9.1 & 0.2 & 35.4 & 0.7 & 1.1 & 33.3 \\
\hline $\mathrm{C} 2$ & $115-145$ & 7.92 & 0.310 & 4.7 & 0.3 & 25.4 & 0.7 & 0.7 & 23.7 \\
\hline \multicolumn{10}{|c|}{ Saçıkara Serisi } \\
\hline Ap & $0-21$ & 8.25 & 0.426 & 4.2 & 1.0 & 56.4 & 1.2 & 1.7 & 53.2 \\
\hline $\mathrm{A} 2$ & $21-41$ & 8.06 & 0.371 & 10.7 & 0.8 & 56.8 & 1.0 & 1.2 & 54.8 \\
\hline Bw & $41-75$ & 8.02 & 0.328 & 19.9 & 0.4 & 54.2 & 0.8 & 1.0 & 52.2 \\
\hline $\mathrm{C} 1$ & $75-101$ & - & - & - & - & - & - & - & - \\
\hline $\mathrm{C} 2$ & $101-130$ & - & - & - & - & - & - & - & - \\
\hline \multicolumn{10}{|c|}{ İmamoğlu Serisi } \\
\hline Ap & $0-14$ & 8.22 & 0.471 & 12.1 & 1.4 & 51.6 & 0.7 & 2.7 & 48.2 \\
\hline Ad & $14-26$ & 7.91 & 0.579 & 10.4 & 1.1 & 51.1 & 0.7 & 2.1 & 48.0 \\
\hline A3 & $26-75$ & 7.98 & 0.473 & 15.9 & 0.9 & 53.5 & 0.8 & 1.3 & 50.3 \\
\hline Bw & $75-96$ & 7.85 & 0.323 & 22.9 & 0.5 & 49.2 & 0.9 & 1.2 & 47.0 \\
\hline $\mathrm{Bk}$ & $96-127$ & 7.96 & 0.335 & 27.8 & 0.4 & 50.2 & 1.2 & 1.2 & 46.0 \\
\hline $\mathrm{C}$ & $127-165$ & 8.01 & 0.565 & 16.3 & 0.4 & 55.3 & 1.6 & 1.2 & 52.1 \\
\hline \multicolumn{10}{|c|}{ Bașkuyu Serisi } \\
\hline Ap & $0-10$ & 8.10 & 0.501 & 3.90 & 2.1 & 46.8 & 0.6 & 2.0 & 43.2 \\
\hline $\mathrm{Ad}$ & $10-24$ & 8.05 & 0.503 & 5.80 & 2.1 & 47.4 & 0.6 & 1.5 & 45.1 \\
\hline $\mathrm{Bk}$ & $24-55$ & 7.91 & 0.491 & 20.2 & 1.6 & 40.9 & 0.7 & 0.8 & 39.2 \\
\hline $\mathrm{Ckm}$ & $55-71$ & - & - & - & - & - & - & - & - \\
\hline $\mathrm{C} 2$ & $71-110$ & - & - & - & - & - & - & - & - \\
\hline & & & & Kap & & & & & \\
\hline Ap & $0-22$ & 8.00 & 0.409 & 4.6 & 1.7 & 39.3 & 0.6 & 1.4 & 36.9 \\
\hline A2 & $22-53$ & 7.95 & 0.333 & 20.1 & 1.5 & 34.1 & 0.6 & 0.7 & 34.1 \\
\hline $\mathrm{Bk}$ & $53-78$ & 7.93 & 0.356 & 38.5 & 1.3 & 34.4 & 0.7 & 0.6 & 33.0 \\
\hline $\mathrm{C}$ & $78-100$ & - & - & - & - & - & - & - & - \\
\hline Ckm & $100+$ & - & - & - & - & - & - & - & - \\
\hline & & & & Killa & & & & & \\
\hline Ap & $0-24$ & 7.92 & 0.441 & 0.0 & 1.4 & 35.5 & 0.6 & 1.6 & 33.1 \\
\hline A2 & $24-67$ & 8.00 & 0.364 & 0.0 & 1.2 & 33.1 & 0.6 & 1.0 & 31.2 \\
\hline Bw & $67-86$ & 7.85 & 0.335 & 4.2 & 0.9 & 29.7 & 0.6 & 0.8 & 27.3 \\
\hline B & $86-104$ & 7.94 & 0.337 & 9.2 & 1.3 & 27.6 & 0.6 & 0.7 & 26.3 \\
\hline $\mathrm{C}$ & $104-150$ & 8.01 & 0.309 & 9.6 & 1.1 & 27.6 & 0.6 & 0.7 & 25.2 \\
\hline & & & & Odab & & & & & \\
\hline Ap & $0-31$ & 7.99 & 0.448 & 30.8 & 2.0 & 39.3 & 0.6 & 1.5 & 37.0 \\
\hline Bw & $31-55$ & 8.04 & 0.655 & 35.9 & 1.9 & 39.1 & 0.7 & 0.8 & 36.7 \\
\hline $\mathrm{Ckm}$ & $55+$ & - & - & - & - & - & - & - & - \\
\hline & & & & Kuyub & & & & & \\
\hline $\mathrm{Ap}$ & $0-19$ & 8.01 & 0.625 & 30.8 & 1.6 & 34.1 & 0.6 & 1.5 & 1.5 \\
\hline Bw & $19-40$ & 8.11 & 0.574 & 35.9 & 1.2 & 32.8 & 0.6 & 0.8 & 0.8 \\
\hline Ckm & $40+$ & - & - & - & - & - & - & - & - \\
\hline
\end{tabular}

OM: Organik madde; KDK: katyon değişim kapasitesi; EC: elektriksel iletkenlik 
Taşlılık yüzey katmanında çok azdır, yüzey topografyası aşırı dalgalıdır. Yüzey ve yüzeyaltı bünyesi tın ve kil tındır. Tüm profil boyunca kireç miktarı \%30.8-35.9 arasında değişim gösteren bu topraklar toprak sınıflamasına göre Xeric Petrocalcid olarak sınıflandırılmıştır. Profil boyunca pH değerleri hafif alkali özellik göstermektedir. Katyon değişim kapasiteleri 39.1-39.3 cmol.kg-1 arasında değişmektedir. Kap serisi, kireç taşı ana materyali üzerinde olușmuștur. Strüktür gelișimi zayıf, kil tın bünyesine sahiptir. Yüzey topografyası dalgalı ve yüzeyi orta taşlıdır. Sı̆̆ profilli topraklardır. Araştırma alanının batı ve kuzey kesimlerinde yayılım göstermektedir. Profilin $\mathrm{pH}$ değerleri 7.938.00 arasında ve EC değerleri 0.333-0.409 dS.m ${ }^{-1}$ arasında değişim göstermektedir. Profil boyunca organik madde miktarı derinliğe bağlı azalmakta olup \%1.3-1.7 arasında değişmektedir. Profil boyunca kireç miktarları \%4.6-8.5 arasındadır. Başkuyu serisi, marn ana materyal üzerinde oluşmuş topraklardır. Profil boyunca kireç miktarı \%3.9020.2 arasında değişmekte olup, profilde kireç benekleri, miselleri ve çörtler bulunmaktadır. Yüzey topoğrafyası hafif dalgalı ve yüzeyde taşlılık yoktur. Katyon değișim kapasitesi 40.9-47.4 cmol.kg-1 arasında değişmektedir. Profilin pH değerleri 7.918.10 arasında değișmekte olup seri topraklarının EC değerleri tuzsuz grubuna dahil edilmiștir. Profil boyunca bünye sınıfı kil tın ve kil hakimdir. Profildeki kuru hacim ağırlığı değerleri ise 1.28-1.39 g. $\mathrm{cm}^{-3}$ arasında ve hidrolik iletkenlik değerleri 2.54$5.33 \mathrm{~cm} . \mathrm{h}^{-1}$ arasındadır.

Kuyubaşı serisi, araştırma alanı topraklarının \%3.5'lik bir kısmını oluşturmaktadır. Marn ve kalker ana materyali üzerinde oluşmuş bu topraklarda kireç miktarı \%30.8-35.9 arasındadır. Seri toprakları sı profilli olup drenaj ve erozyon sorunu gözlenmemiștir. Profil boyunca kil tın bünyesi hakimdir. Kuru hacim ağırlığ değerleri 1.36-1.41 g. $\mathrm{cm}^{-3}$ arasında değişmektedir. Profil $\mathrm{pH}$ değerleri hafif alkali grubuna dahil edilmiștir ve profil EC değerlerine göre tuzsuz olarak bulunmuştur. Katyon değişim kapasiteleri 32.8-34.1 cmol.kg-1 arasında değişmektedir. Kıllar serisi, alüvyal dolgu üzerinde gelişen bu seri toprakları çok derindir. Çalışma alanın orta kısımlarında yayılım gösteren bu seri, derelerin getirdiği çökeller üzerinde olușmuș topraklardır. Profil boyunca pH değerleri 7.92-8.01 arasında değișim göstermekte olup EC değerleri ise 0.309-0.441 dS.m ${ }^{-1}$ arasındadır. Seri toprakları orta ince tekstürlü ve strüktür gelişimi vardır. Profil boyunca kum miktarı \%60.16-66.39 arasında değişmekte olup kuru hacim ağırlığı değerleri 1.481.70 g.cm ${ }^{-3}$ arasında değişmektedir. Profildeki hidrolik iletkenlik değerleri 2.60-5.43 cm.h ${ }^{-1}$ arasında, katyon değișim kapasiteleri 32.8-34.1 cmol.kg-1 arasında değişmektedir. Saçıkara serisi toprakları marn ana materyali üzerinde oluşmuş, depolanmış killerdir. Toprak profilinde yüksek oranda kil içermekte ve bu nedenle kurak dönemlerde derin çatlaklar oluşmaktadır. Çok derin profile sahip olan bu seri topraklarının kireç miktarları \%4.2-19.9 arasında değişmekte olup profil boyunca kil tın ve kil bünyesi hakimdir. Profildeki pH değişim 8.02-8.25 arasında iken, profil EC değerleri 0.328-0.426 dS.m ${ }^{-1}$ arasında değişim göstermektedir. Profildeki katyon değişim kapasiteleri 54.2-56.8 cmol.kg-1 arasında, hidrolik iletkenlik değerleri ise 1.50-9.82 $\mathrm{cm} . \mathrm{h}^{-1}$ arasındadır. Çatalca serisi killi tınlı tekstürden profil boyunca kumlu killi tın tekstüre doğru geçen bu seri topraklarında kireç miktarı \%1.0-9.1 arasındadır. Profildeki hidrolik iletkenlik değerleri 1.30-1.77 $\mathrm{cm} . \mathrm{h}^{-1}$ arasında ve katyon değişim kapasiteleri 25.452.1 cmol.kg-1 arasında değişim göstermektedir. Profil boyunca $\mathrm{pH}$ değerleri hafif alkali karakterli olup, profildeki EC değișimi 0.27-0.445 dS.m ${ }^{-1}$ arasında değişmektedir. Organik madde miktarındaki değișim ise \%0.2-1.5 arasındadır.

İmamoğlu serisi, profil boyunca kireç miktarı \%10.427.8 arasında değișmekte olup, profil kil tın ve kil bünyesine sahip olan bu topraklar çok derindir. Strüktür gelişimi görülmekle beraber, alt horizonlarda yoğun şekilde kireç miselleri ve cepleri bulunmaktadır. Çalışma alanın orta ve batı kısımlarında yayılım gösteren bu seri toprakları, vadi tabanı dolgularında yer almaktadır. Profildeki hidrolik iletkenlik değerleri 0.94-5.85 cm.h ${ }^{-1}$ arasında ve katyon değişim kapasiteleri 49.2-55.3 cmol.kg-1 arasındadır. Profil boyunca pH değerleri hafif alkali karakterli olup, profildeki EC değişimi 0.323-0.565 dS.m-1 arasındadır. Hacıfakılı serisi, profil boyunca kireçli olup, taşlılık sorunu bulunmamaktadır. Killi bünyeye sahip olup, strüktür gelișimi de görülmekle birlikte kireç miselleri ve nodüller de gözlenmiştir. Çalışma alanının güney doğu kısımlarında yayılım gösteren marn ana materyali üzerinde oluşmuş çok derin topraklardır. Profil boyunca pH değerleri 7.94-8.19 arasında değişim göstermekte olup, profildeki EC değișimi 0.27-0.42 $\mathrm{dSm}^{-1}$ arasındadır. Katyon değişim

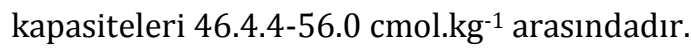


Çizelge 3. Altınova TİGEM araştırma alanı toprak profilleri fiziksel analiz sonuçları

\begin{tabular}{|c|c|c|c|c|c|c|c|c|}
\hline \multirow{2}{*}{ Horizon } & \multirow{2}{*}{$\begin{array}{l}\text { Derinlik } \\
\mathrm{cm}\end{array}$} & \multicolumn{4}{|c|}{ Bünye, (\%) } & \multirow{2}{*}{$\begin{array}{c}\text { Hidrol. İlet. } \\
\mathrm{cm} \cdot \mathrm{h}^{-1}\end{array}$} & \multirow{2}{*}{$\begin{array}{c}\text { Hacim ağırlığı } \\
\text { g.cm }\end{array}$} & \multirow{2}{*}{$\begin{array}{c}\text { Sat. } \\
\%\end{array}$} \\
\hline & & Kil & Silt & Kum & Sinif & & & \\
\hline \multicolumn{9}{|c|}{ Altınova Serisi } \\
\hline Ap & $0-21$ & 30.8 & 29.1 & 40.2 & CL & 0.654 & 1.31 & 43.8 \\
\hline Bw1 & $21-45$ & 35.1 & 24.9 & 40.0 & CL & 2.676 & 1.41 & 53.4 \\
\hline Bw2 & $45-72$ & 34.9 & 24.8 & 40.4 & CL & 1.475 & 1.42 & 56.3 \\
\hline $\mathrm{Ck}$ & $72-107$ & 11.7 & 49.4 & 38.9 & $\mathrm{~L}$ & 3.635 & 1.41 & 53.3 \\
\hline $\mathrm{C} 2$ & $107-152$ & 11.8 & 18.5 & 69.8 & SL & 2.349 & 1.36 & 49.3 \\
\hline \multicolumn{9}{|c|}{ Hacıfakılı Serisi } \\
\hline Ap & $0-21$ & 39.74 & 25.20 & 35.07 & CL & 1.24 & 1.31 & 56.9 \\
\hline A2 & $21-40$ & 40.22 & 21.19 & 38.59 & $\mathrm{C}$ & 10.68 & 1.42 & 61.0 \\
\hline A3 & $40-63$ & 42.07 & 25.32 & 32.61 & $\mathrm{C}$ & 4.78 & 1.41 & 70.3 \\
\hline Bw1 & $63-82$ & 52.43 & 16.64 & 30.93 & $\mathrm{C}$ & 5.30 & 1.42 & 75.6 \\
\hline Bw2 & $82-100$ & 43.74 & 29.29 & 26.97 & $\mathrm{C}$ & 5.60 & 1.36 & 66.9 \\
\hline $\mathrm{C}$ & $100-125$ & - & - & - & - & - & - & - \\
\hline \multicolumn{9}{|c|}{ Çatalca Serisi } \\
\hline Ap & $0-18$ & 35.22 & 22.52 & 42.26 & $\mathrm{CL}$ & 3.69 & 1.30 & 48.47 \\
\hline $\mathrm{A} 2$ & $18-55$ & 44.13 & 14.20 & 41.68 & $\mathrm{C}$ & 9.60 & 1.60 & 61.87 \\
\hline Bw & $55-74$ & 39.68 & 15.20 & 45.12 & CL & 8.78 & 1.63 & 55.99 \\
\hline $\mathrm{BCk}$ & 74-92 & 28.47 & 10.06 & 61.47 & SCL & 17.06 & 1.71 & 47.44 \\
\hline $\mathrm{Ck}$ & $92-115$ & 30.49 & 12.12 & 57.39 & SCL & 16.53 & 1.75 & 44.32 \\
\hline $\mathrm{C} 2$ & $115-145$ & 24.11 & 9.61 & 66.29 & SCL & 5.08 & 1.77 & 39.30 \\
\hline \multicolumn{9}{|c|}{ Saçıkara } \\
\hline Ap & $0-21$ & 35.45 & 29.06 & 35.49 & CL & 1.50 & 1.33 & 51.91 \\
\hline $\mathrm{A} 2$ & $21-41$ & 46.49 & 25.01 & 28.50 & $\mathrm{C}$ & 9.82 & 1.44 & 63.91 \\
\hline Bw & $41-75$ & 52.81 & 22.80 & 24.39 & $\mathrm{C}$ & 7.58 & 1.38 & 68.53 \\
\hline $\mathrm{C} 1$ & $75-101$ & - & - & - & - & - & - & - \\
\hline $\mathrm{C} 2$ & $101-130$ & - & - & - & - & - & - & - \\
\hline \multicolumn{9}{|c|}{ İmamoğlu Serisi } \\
\hline Ap & $0-14$ & 31.10 & 33.23 & 35.67 & CL & 5.58 & 1.41 & 51.53 \\
\hline Ad & $14-26$ & 39.88 & 29.18 & 30.94 & CL & 1.19 & 1.46 & 51.35 \\
\hline A3 & $26-75$ & 47.52 & 21.60 & 30.89 & $\mathrm{C}$ & 3.02 & 1.41 & 70.69 \\
\hline Bw & $75-96$ & 59.39 & 20.71 & 19.89 & $\mathrm{C}$ & 0.94 & 1.39 & 100.73 \\
\hline $\mathrm{Bk}$ & $96-127$ & 61.66 & 20.75 & 17.58 & $\mathrm{C}$ & 4.32 & 1.38 & 101.88 \\
\hline $\mathrm{C}$ & $127-165$ & 40.34 & 23.03 & 36.63 & $\mathrm{C}$ & 5.85 & 1.37 & 73.61 \\
\hline \multicolumn{9}{|c|}{ Başkuyu Serisi } \\
\hline Ap & $0-10$ & 35.27 & 32.09 & 32.63 & $\mathrm{CL}$ & 3.80 & 1.28 & 46.04 \\
\hline Ad & $10-24$ & 35.28 & 31.04 & 33.68 & CL & 5.33 & 1.39 & 46.82 \\
\hline $\mathrm{Bk}$ & $24-55$ & 43.38 & 22.94 & 33.68 & $\mathrm{C}$ & 2.54 & 1.35 & 62.79 \\
\hline $\mathrm{Ckm}$ & $55-71$ & - & - & - & - & - & - & - \\
\hline $\mathrm{C} 2$ & $71-110$ & - & - & - & - & - & - & - \\
\hline \multicolumn{9}{|c|}{ Kap Serisi } \\
\hline Ap & $0-22$ & 29.21 & 23.68 & 47.11 & SCL & 3.03 & 1.49 & 43.36 \\
\hline A2 & $22-53$ & 30.25 & 27.87 & 41.88 & $\mathrm{C}$ & 1.96 & 1.52 & 56.77 \\
\hline $\mathrm{Bk}$ & $53-78$ & 43.80 & 18.77 & 37.43 & $\mathrm{C}$ & 9.77 & 1.50 & 56.98 \\
\hline $\mathrm{C}$ & $78-100$ & - & - & - & - & - & - & - \\
\hline $\mathrm{Ckm}$ & $100+$ & - & - & - & - & - & - & - \\
\hline \multicolumn{9}{|c|}{ Kıllar Serisi } \\
\hline $\mathrm{Ap}$ & $0-24$ & 21.59 & 12.01 & 66.39 & SCL & 5.43 & 1.48 & 38.50 \\
\hline $\mathrm{A} 2$ & $24-67$ & 26.04 & 9.03 & 64.94 & SCL & 2.60 & 1.64 & 50.81 \\
\hline Bw & $67-86$ & 22.66 & 11.00 & 66.34 & SCL & 3.76 & 1.58 & 40.74 \\
\hline $\mathrm{B}$ & $86-104$ & 21.60 & 12.02 & 66.38 & SCL & 4.91 & 1.64 & 40.56 \\
\hline $\mathrm{C}$ & $104-150$ & 21.62 & 18.23 & 60.16 & SCL & 2.85 & 1.70 & 44.66 \\
\hline & & & & dabaşı S & & & & \\
\hline Ap & $0-31$ & 26.09 & 28.94 & 44.97 & $\mathrm{~L}$ & 3.33 & 1.32 & 45.44 \\
\hline Bw & $31-55$ & 29.26 & 26.87 & 43.87 & $\mathrm{CL}$ & 2.48 & 1.30 & 59.32 \\
\hline $\mathrm{Ckm}$ & $55+$ & - & - & - & - & - & - & - \\
\hline & & & & yubaşı & & & & \\
\hline $\mathrm{Ap}$ & $0-19$ & 34.44 & 28.92 & 36.64 & CL & 5.61 & 1.41 & 46.55 \\
\hline Bw & $19-40$ & 32.42 & 26.89 & 40.69 & CL & 3.98 & 1.36 & 61.70 \\
\hline Ckm & $40+$ & - & - & - & - & - & - & - \\
\hline
\end{tabular}


Çizelge 4. Araştırma alanı toprak serilerinin dağılımı

\begin{tabular}{|c|c|c|c|c|}
\hline \multirow{2}{*}{ Seri Adı } & \multirow{2}{*}{ Sembol } & \multirow{2}{*}{ Ana materyal } & \multicolumn{2}{|c|}{ Alan } \\
\hline & & & ha & $\%$ \\
\hline Altınova & Ao & Marn & 1020.3 & 15.8 \\
\hline Bașkuyu & $\mathrm{Bk}$ & Marn & 556.2 & 8.6 \\
\hline Çatalca & $\tilde{A} t$ & Marn & 245.1 & 3.8 \\
\hline Hacıfakılı & $\mathrm{Hc}$ & Marn & 518.7 & 8.0 \\
\hline Imamoğlu & $\operatorname{Im}$ & Kireçtașı & 557.1 & 8.6 \\
\hline Kap & Kp & Kireçtaşı & 807.4 & 12.5 \\
\hline Kıllar Köyü & $\mathrm{Kk}$ & Aluvyal & 418.6 & 6.5 \\
\hline Kuyubașı & $\mathrm{Kb}$ & Marn- Kalker & 225.8 & 3.5 \\
\hline Odabaşı & $\mathrm{Ob}$ & Marn- Kalker & 1717.6 & 26.5 \\
\hline Saçıkara & Sk & Marn & 404.2 & 6.2 \\
\hline \multicolumn{2}{|c|}{ Toplam } & & 6471.0 & 100.0 \\
\hline
\end{tabular}

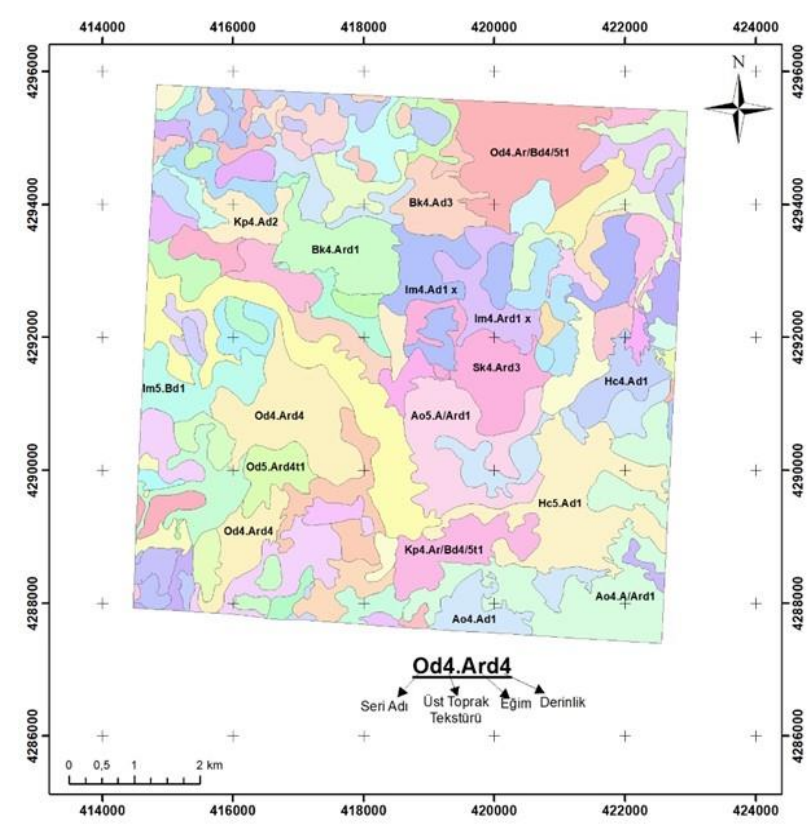

Şekil 2. Araştırma alanı toprak seri haritası

Altınova serisi çalışma alanının \%15.8'ini oluşturan, marn ana materyali üzerinde düz-düze yakın eğimlerde oluşmuş çok derin topraklardır. Profil boyunca çok kireçli olup, taşlıllk sorunu yoktur. Ayrıca strüktür gelişimi görülmekte olup kireç miselleri ve nodülleri bulunmaktadır. Profildeki hidrolik iletkenlik değerleri çok düşük olup 0.65$3.63 \mathrm{~cm} . \mathrm{h}^{-1}$ arasında ve katyon değişim kapasiteleri 14.3-42.8 cmol. $\mathrm{kg}^{-1}$ arasında değişmiştir. Profil boyunca $\mathrm{pH}$ değerleri hafif alkali karakterli olup, profildeki EC değişimi $0.4-1.2 \mathrm{dS} . \mathrm{m}^{-1}$ arasında değişmekte olup tuzluluk problemi görülmemektedir.

\section{Araştırma alanları topraklarının toprak taksonomisine göre sınıflandırılması}

Araştırma alanı detaylı toprak etüt çalışmaları sonucunda toprak siniflamasina (Soil Survey Staff, 2014) göre iki Ordo, 4 Alt Ordo ve 5 Alt Grup içerisine dahil edilmiştir. Ayrıca, FAO-WRB (2014) sinıflamasına göre Cambisol, Calcisol ve Vertisol Referans Toprak Grubu içerisinde değerlendirilmiştir (Çizelge 5). Araştırma alanı içerisinde, Altınova, Hacıfakılı serileri, toprak yüzeyinden $100 \mathrm{~cm}$ içinde bir veya daha fazla katmanında normal yıl içerisinde sulanan veya doygun şartlarda olmadığı, toprak yüzeyinden 100 $\mathrm{cm}$ içerisinde bir veya daha fazla toprak katmanı normal yll içerisinde 1 ay veya daha fazla doygun durumda olmadığı için ve toprak yüzeyinden $150 \mathrm{~cm}$ içerisinde duripan veya petrocalcic veya petrocalcic horizona sahip olmadığı için Xeric Haplocambid alt grubuna dahil edilmişlerdir ve araştırma alanında \%23.8'lik 1539.0 ha'lık bir alanda yaylım göstermektedirler. Ayrıca, FAO-WRB (2014) sinıflamasına göre ise bu seriler Calcaric Cambisol ve Vertic Calcisol olarak sınıflandırılmıştır. Araştırma alanı içerisinde, Başkuyu, Kap, Kuyubaşı ve Odabaşı serileri \% 5'den daha fazla $\mathrm{CaCO}_{3}$ miktarına sahip olduğu için, $15 \mathrm{~cm}$ 'den daha kalın olması ve altındaki horizondan $\% 5$ daha fazla $\mathrm{CaCO}_{3}$ içeriğine sahip olması nedeniyle ve biriken kirecin çimentolaşmıș olması nedeniyle Xeric Petrocalcid alt grubuna dahil edilmişlerdir ve araştırma alanında \%42.5'lik 2750.8 ha'llk bir alanda yayılım göstermektedir. Araștırma alanı içerisinde, Çatalca ve İmamoğlu serileri toprak yüzeyinden $100 \mathrm{~cm}$ içerisinde petrocalcic horizon bulunmaması nedeniyle Xeric Haplocalcidler grubuna dahil edilmiştir ve araştırma alanında \%21'lik 1358.4 ha'llk bir alanda yayılım göstermektedir. FAO-WRB (2014) sinıflamasına göre ise bu seriler Vertic Cambisol ve Ochric Calcisol olarak sınıflandırılmıștır. Araştırma alanında Saçıkara serisi ise Vertisol Ordosuna, toprak yüzeyinden $100 \mathrm{~cm}$ içerisinde calcic horizon bulunması nedeniyle Calcixerert Büyük Grubuna dahil edilmiştir. Araştırma alanının \%6.2'lik kısmını oluşturmaktadır. Ayrıca, FAO-WRB (2014) sinıflamasına göre ise Haplic Vertisol olarak sinıflandırılmıştır. 
Çizelge 5. Toprak serilerinin toprak sınıflama ve FAO-WRB sınıflandırılması

\begin{tabular}{|c|c|c|c|c|c|}
\hline \multirow{2}{*}{ Seri Adı } & \multicolumn{4}{|c|}{ Toprak Taksonomisi -2014 } & \multirow{2}{*}{ FAO-WRB-2014 } \\
\hline & Ordo & Alt Ordo & Büyük Grup & Alt Grup & \\
\hline Altınova & Aridisol & Cambic & Haplocambid & Xeric Haplocambid & Calcaric Cambisol \\
\hline Başkuyu & Aridisol & Calcid & Petrocalcid & Xeric Petrocalcid & Petric Calcisol \\
\hline Çatalca & Aridisol & Cambid & Haplocambid & Xeric Haplocambid & Vertic Cambisol \\
\hline Hacıfakılı & Aridisol & Calcid & Haplocalcid & Xeric Haplocalcid & Vertic Calcisol \\
\hline Imamoğlu & Aridisol & Calcid & Haplocalcid & Xeric Haplocalcid & Ochric Calcisol \\
\hline Kap & Aridisol & Calcid & Petrocalcid & Xeric Petrocalcid & Petric Calcisol \\
\hline Kıllar Köyü & Aridisol & Cambid & Haplocambid & Xeric Haplocambid & Fluvic Cambisol \\
\hline Kuyubaşı & Aridisol & Calcid & Petrocalcid & Xeric Petrocalcid & Petric Calcisol \\
\hline Odabaşı & Aridisol & Calcid & Petrocalcid & Xeric Petrocalcid & Petric Calcisol \\
\hline Saçıkara & Vertisol & Xerert & Calcixerert & Typic Calcixerert & Haplic Vertisol \\
\hline
\end{tabular}

\section{Haritaların büyük grup düzeyinde ve bazı faz özelliklerinin karşılaştırılması}

Araştırma alanı 1938 Eski Amerikan Sınıflama Sistemine göre yapılmış Büyük Toprak Gruplarını içeren toprak haritası Şekil 3'de verilmiştir. Şekil 3'den görüldüğü gibi, araştırma alanı büyük toprak grubu haritasında Kahverengi (B) ve Kırmızı Kahverengi (F) toprak gruplarına dahil edilmiştir. Bununla birlikte, topak taksonomisine göre seri düzeyinde yapılmış toprak haritasında 10 adet toprak serisi belirlenmiştir. Çalışma alanının \%37.17'si kahverengi toprak grubuna, \%62.83'ü ise kırmızı kahverengi toprak grubundadır. Bununla birlikte detaylı yapılan toprak haritası sonuçlarına göre, Kahverengi Toprak Grubunun \%26.20'si Altınova, \%16.83'ü Başkuyu, \%14.01 Hacıfakılı ve \%10.07'si ise Saçıkara serilerinden oluşmaktadır. Ayrıca Kırmızı Kahverengi toprak grubunun \%38'i Odabaşı, \%15'i Kap ve \%9.59'u Altınova serilerden oluşmaktadır. Benzer şekilde araştırma alanı büyük toprak haritası ile toprak alt grup haritası karşılaştırıldığında, Kahverengi Büyük Toprak Grubu \%40.21'i Xeric Haplocambid, \%29.04'ü Xeric Haplocalcid, \%16.12'si Xeric Petrocalcid alt gruplarına dahil edilmiştir. Araştırma alanı ait toprakların alt gurup toprak dağılım haritası Şekil 4'de verilmiștir. Buna göre, Kırmızı Kahverengi Toprak Grubunun ise \%58.52'si Xeric Petrocalcid, \%16.73'ü Xeric Haplocalcid ve \%14.34'ü Xeric Haplocambid alt grubuna dahil edilmiştir. Xeric Petrocalcid'ler 2750.8 ha'llk (\%42.5) bir alanla en geniş yayılımı göstermektedir. Xeric Petrocalcid'leri, $\% 23.8$ 'lik (1539.0 ha) bir oranla Xeric Haplocambid'ler ve \%21.0'lı (1358.4 ha) bir yayılımla Xeric Haplocalcid'ler takip etmektedir. Araştırma alanı 1938 Eski Amerikan Sınıflama Sistemine göre yapılmış toprak derinlik haritası ile güncel detaylı toprak derinlik haritası Şekil 5'de verilmiştir. Araştırma alanı 1938 Eski Amerikan Sınıflama Sistemine göre yapılmış toprak derinlik haritasının \%13.18'i derin, \%37.81'i orta derin, \%45.01'i sı̆̆ ve \%3.98'i çok sı̆̆ grubuna dahil edilmiştir.

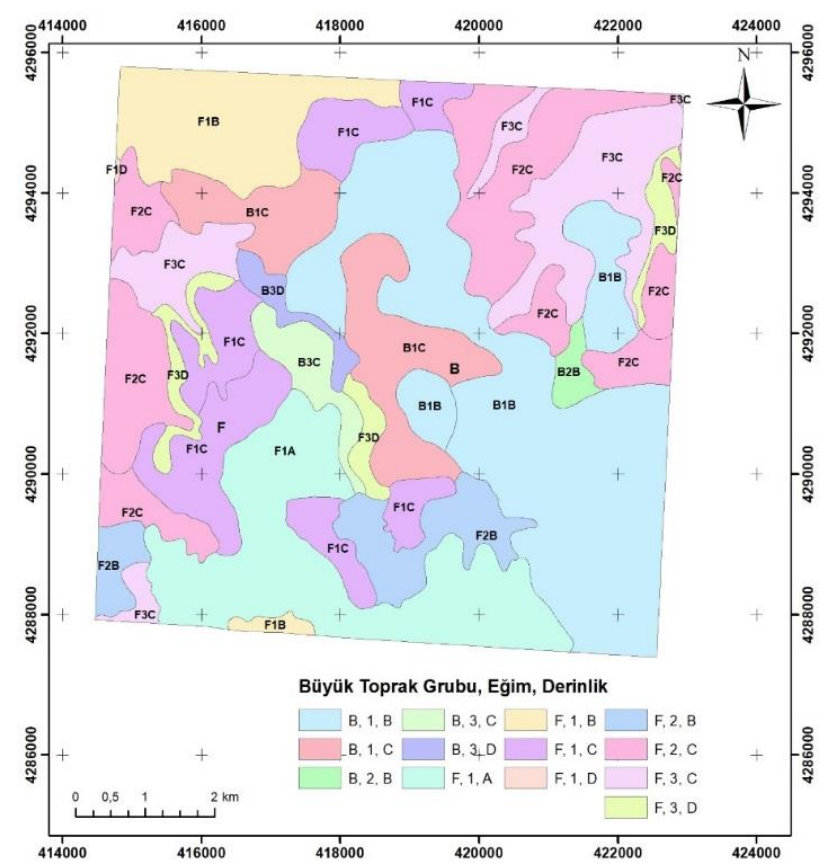

Şekil 3. Araştırma alanı 1938 eski amerikan sınıflama sistemine göre yapılmış büyük toprak gruplarını içeren toprak haritası

İstikşafi düzeyde yapılan 1938 sistemine göre yapılan toprak haritasında derin (A) grubuna dahil olan kısmının \%31.07'sı detaylı toprak haritasındaki d1 (Derin) grubuna, \%34.18'i d4 (çok sığ) grubuna; orta (B) grubuna dahil olan kısmının ise \%61.43'ü detaylı toprak haritasındaki d1 (derin), \%16.13'ü d3 (sığ), \%9.71'i d4/5 (kompleks) sınıfına; sı̆̆ (C) grubuna dahil olan kısmının \%35.16'sı d1(derin), \%24.14'ü d4 (çok sığ) grubuna, \%14.59'u d4/5 (kompleks) grubuna dahil edilmiştir.

Araştırma alanı 1938 Eski Amerikan Sınıflama Sistemine göre yapılmış toprak eğim haritası ile güncel detaylı eğim haritası Şekil 6'da verilmiştir. 


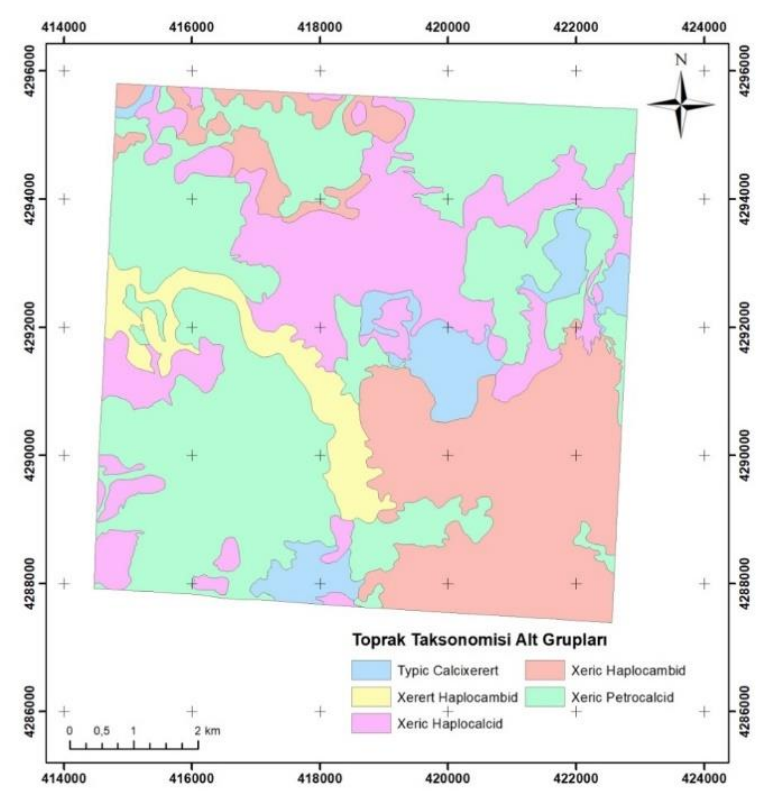

Şekil 4. Araştırma alanı ait toprakların alt gurup toprak dağılım haritası

1938 Eski Amerikan Sinıflama Sistemine göre istikşafi düzeyde yapılan toprak haritasında eğim yüzdesi düz, düze yakın (\%64.76), hafif eğimli $(\% 20.04)$ ve orta eğimli (\%15.20) olmak üzere 3 gruba ayrılmıştır. Detaylı yapılan toprak haritasında ise eğim 8 farklı gruba ayrılmıştır. İstikşafi düzeyde yapılan toprak haritasında düz-düze yakın eğimli olan alanların \%36.71'i detaylı toprak haritasındaki düze yakım eğimli (A) grubuna, \%35.69'u hafif dalgalı (Ar) grubuna, \%15.77'si kompleks (A/Ar) grubuna; hafif eğimli grubuna dahil olanların \%31.30'u kompleks (Ar/B) grubuna, \%25.40'ı hafif dalgalı (Ar) grubuna, \%17.37'si düze yakın eğim (A) grubuna; orta eğimli olan alanların \%35.55'i kompleks (Ar/B) grubuna, \%29.76'sı hafif dalgalı (Ar) grubuna ve \% 15.38'i düze akın eğim (A) grubuna dahil edilmiştir.

\section{Sonuç}

Araştırma alanında dağılım gösteren farklı özelliklere sahip topraklar seri düzeyinde detaylı toprak haritası yapılmasının yanı sıra, Eski 1938 Amerikan sınıflamasına göre yapılmış toprak haritası gerek bazı faz özellikleri (eğim ve toprak derinliği) gerekse de yeni yaklaşmalı toprak taksonomisi ve FAO-WRB sinıflardaki taksonlar arasında karşılaștırmalar yapılmıştır. 1980'li yıllarda Topraksu Genel Müdürlüğü tarafından büyük toprak grubu düzeyinde yapılan toprak etüt çalışmaları 1938 Eski Amerikan sinıflandırma sisteminde dayandırılarak yapılmıştır. Fakat bu sistem, pedogenetik bir sistem üzerine dayandırılmış olması ve zaman içerisinde toprak bilimindeki gelişmelere bağlı olarak yeryüzünde yeni tanımlanan birçok toprağın sinıflandırılmasına cevap verememesi nedeniyle çoğu ülkeler tarafından terk edilmiştir. Bu nedenle son yıllarda geliștirilen ve uluslararası yaygın olarak kullanılan toprak sınıflandırma sistemleri, ölçülebilir ve gözlenebilir toprak karakteristikleri göz önüne alınarak ve morfometrik esaslara dayanılarak yapılmaktadır. Örneğin araştırma alanında 1938 sınıflandırma sistemine göre Kahverengi Toprak Grubunu Altınova, Başkuyu, Hacıfakılı ve Saçıkara serilerini kapsarken, Kırmızı Kahverengi toprak grubu Odabaşı, Kap ve Altınova serilerden oluşmaktadır.
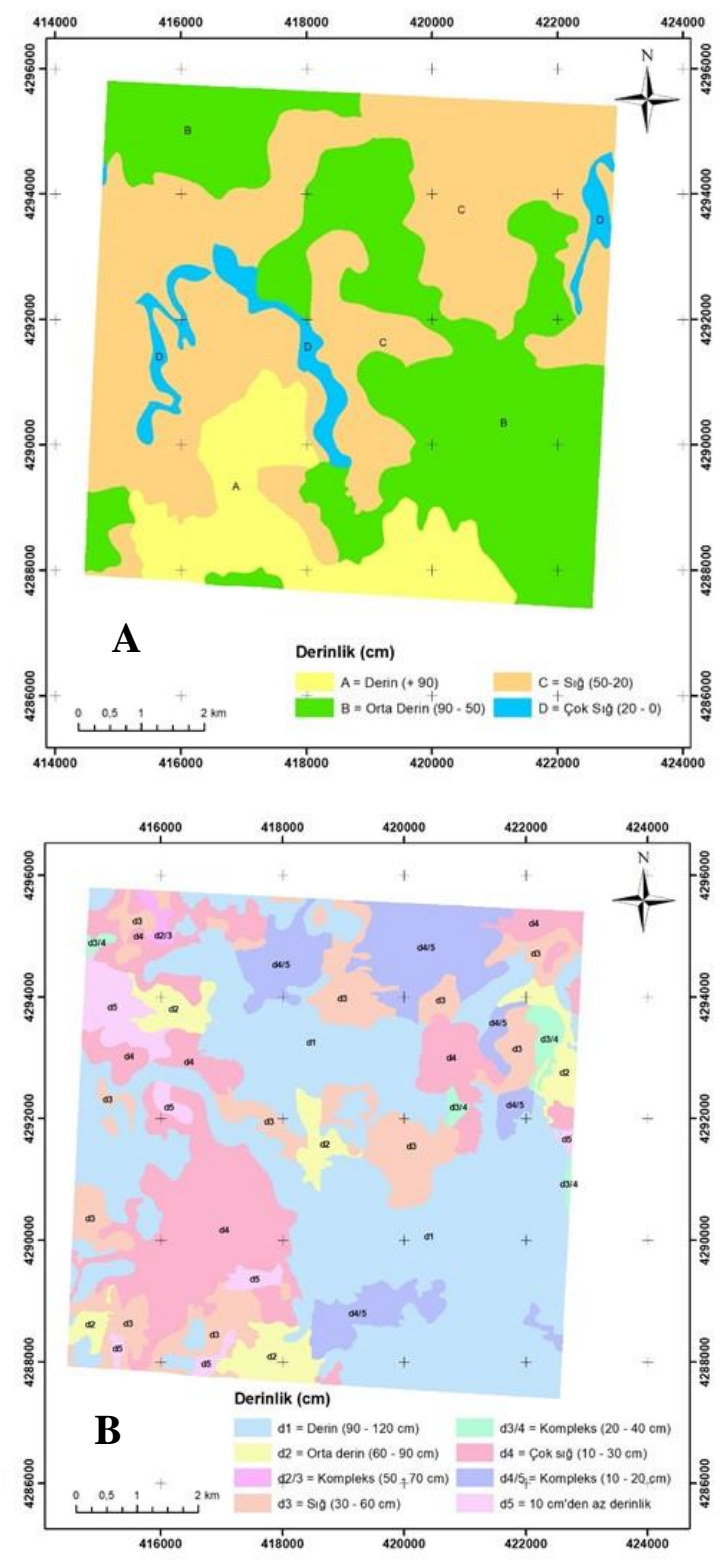

Şekil 5. Araştırma alanı 1938 eski amerikan sınıflama sistemine göre (A) ve güncel toprak derinlik haritası

(B). 

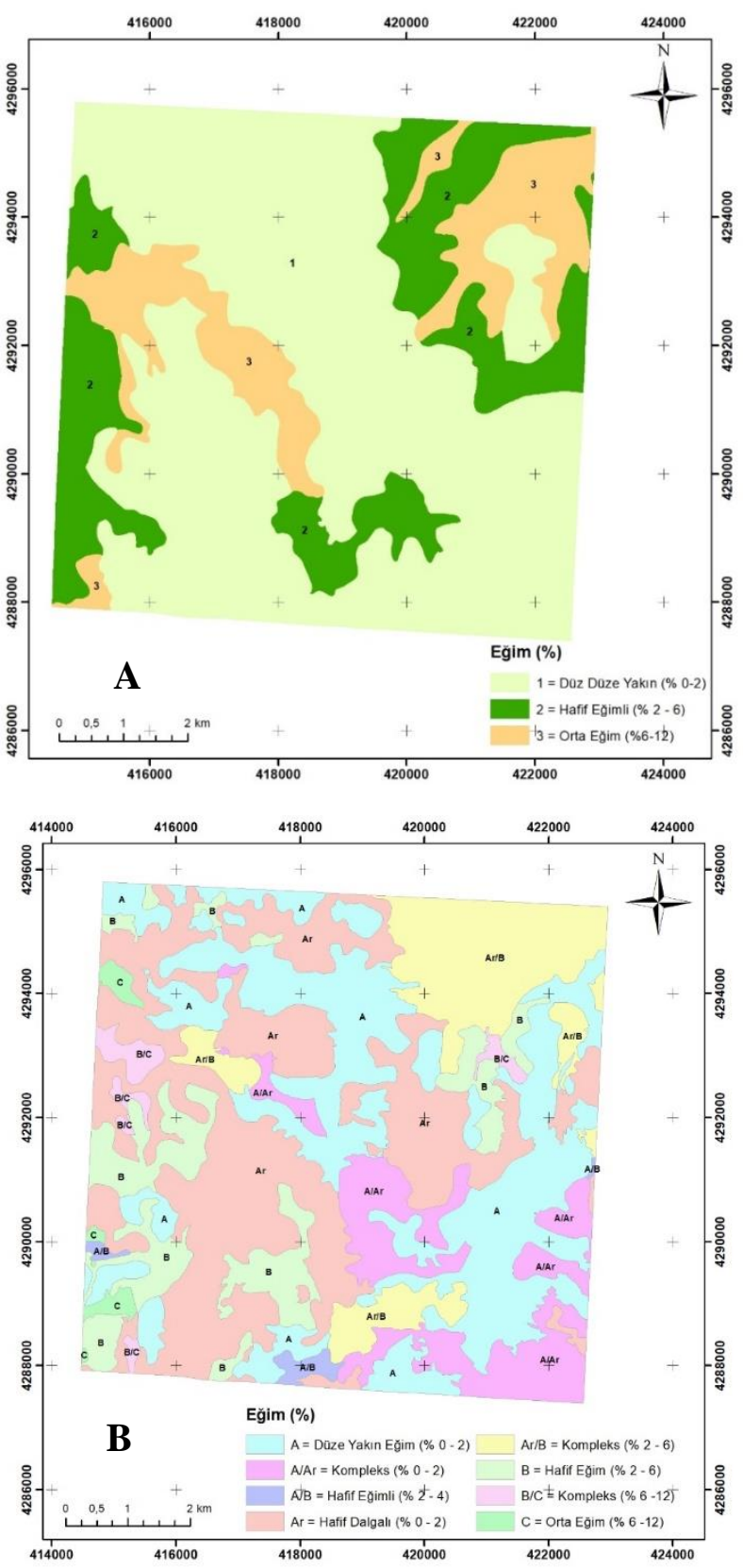

Şekil 6. Araştırma alanı 1938 Eski Amerikan Sınıflama Sistemine göre (A) ve güncel toprak eğim haritası (B).

Büyük toprak grubunda ise Kahverengi ve Kırmızı Kahverengi Büyük Toprak Grupları toprak taksonomisinde Haplocambid, Haplocalcid, Petrocalcid gruplarını dahil edilirken, FAO-WRB sinıflamasında Camisol, Calsisol ve Vertisol Referans Toprak grubuna dahil edilmiştir. Ayrıca, yapılan bu çalışma ile mevcut bölge toprakları hakkındaki veriler güncelleştirilerek uluslararası standarda ulaştırılmış, farklı ülkelerdeki kullanıcıların yararlanmasına imkan sağlanmıştır.

\section{Teşekkür}

Bu çalışmada TÜBİTAK tarafından desteklenen 110 o 729 nolu proje kapsamında elde edilen veriler kullanılmıştır. TÜBiTAK'a ve proje ekibine katkılarından dolayı teşekkür ederim.

\section{Kaynaklar}

Akbaş, F., Yıldız, H., 2004. Toprak özelliklerinin haritalanmasinda jeoististiksel tekniklerin kullanımı. III. Coğrafi bilgi Sistemleri Bilişim Günleri (6-9 Ekim 2004, İstanbul) Bildirileri, 1-10.

Başkan, O., Erpul, G. and Dengiz, O., 2009. Comparing the efficiency of ordinary kriging and cokriging for spatial estimation of the Atterberg limits using selected soil physical properties. Clay Minerals, 44: 181-193.

Başayiğit, L., Şenol, H., Müjdeci, M., 2008. Isparta İli meyve yetiştirme potansiyeli yüksek alanların bazı toprak özelliklerinin coğrafi bilgi sistemleri ile haritalanması. Süleyman Demirel Üniversitesi Ziraat Fakültesi Dergisi, 3(2): 1-10.

Bayramin, İ., Kılıç, Ş., Dengiz, O., Başkan, O., Tunçay, T., Yıldırım, A., Koç, A., Öğütmen, Ç., 2013. Radar görüntülerinin toprak etüt ve haritalama çalışmalarında kullanımı. TUBİTAK TOVAG 1100 729 nolu TOVAG Projesi Sonuç Raporu.

Blake, G. R., Hartge, K. H., 1986. "Bulk Density and Particle Density. In Methods of Soil Analysis, 363-375". In: Part I, Physical and Mineralogical Methods (Second edition), A. Klute (ed.), ASA and SSSA Agronomy Monograph, No:9, Madison, WI., pp: 363-381.

Bouyocous, G.J., 1951. A recalibration of the hidrometer method for making mechanical analysis of soils. Agronomy Journal, 43: 435-438.

Coşkun, A., Dengiz, O., 2016. Samsun Terme Havzası bazı temel fizyografik karakteristiklerin belirlenmesi ve tarımsal taşkın alanlarının toprak haritalanması. Türkiye Tarımsal Araştırmalar Dergisi, 3:1-13.

Çağlar, K.ö., 1958. Toprak İlmi. A.Ü. Ziraat Fakültesi Yayınları, No: 10.

Çullu, M.A., 2012. Toprak etüt haritalama ve toprak yönetimi gerekliliği. Toprak Bilimi ve Bitki Besleme Dergisi, 1(1): 23-25.

Dengiz, O., Bayramin, İ., 2003. Ankara Gölbaşı topraklarının farklı toprak sinıflandırma sistemlerine göre sinıflandırılması. Harran Üniversitesi Ziraat Fakültesi Dergisi, 7: 61-68.

Dengiz, 0., 2007. Characteristics and classification of arid region soils: Salt Lake specially protected area 
(Tuz Gölü-Turkey). Asian Journal of Chemistry, 19 (3): 2316-2324.

Dengiz, O., Göl, C., Öztürk, E., Yakupoğlu, T., 2010. Fluviyal yerşekilleri üzerinde oluşmuş farklı toprak dağılımların belirlenmesi ve sınıflaması. Selçuk Tarım ve Gıda Bilimleri Dergisi, 24 (1): 19-27.

Dengiz, O., Başkan, O., 2010. Characterization of soil profile development on different landscape in semi-arid Region of Turkey a case study; Ankara-Soğulca catchment. Anadolu Tarım Bilimleri Dergisi, 25 (2): 106-112.

Dengiz, O., Başkan, O., Cebel, H., 2015. Ankara Çatalkaya havzası temel toprak özellikleri ve sınıflaması. Toprak Bilimi ve Bitki Besleme Dergisi, 3 (1): 16 31.

Erkocak, A., Dengiz, O., Kılış, Ş., 2010. Land use capability classification data with land forms using GIS case study; Samsun-Bafra District. Anadolu Tarım Bilimleri Dergisi, 25 (S-2): 102-107.

FAO-WRB. 2014. World reference base for soil resources 2014. International soil classification system for naming soils and creating legends for soil maps. World Soil Resources Reports, No:106 p.203.

Hendershot, W. H., Lalande, H. Duquette, M., 1993. "Soil Reaction and Exchangeable Acidity", In Soil Sampling and Methods of Analysis, M.R.Carter (ed.), Canadian Society of Soil Science.

Jackson, M.L., 1958. Soil Chemical Analysis. Presence Hall Inc. Engleewood Cliffs, NJ. USA.

Klute, A. and Dirksen, C., 1986. “ Hydraulic Conductivity and Diffusivity Laboratory Methods", In Methods of Soil Analysis", A. Klute (ed.), Part I, Physical and Mineralogical Methods (Second edition), pp: 687732. ASA and SSSA Agronomy Monograph No.9, Madison, WI.
Kurşun, G., Dengiz, O., 2018. Arid karasal ekosistem koşulları altında oluşmuş toprakların sınıflaması ve dağılımlarının belirlenmesi. Toprak Su Dergisi, 7(2): 1-11.

Oakes, H., 1958. Türkiye toprakları. Türk Yüksek Ziraat Mühendisleri Birliği Neşriyatı. Sayı: 18, 224 s.

Rhoades, J.D., 1982. "Cation Exchange Capacity". In: Methods of Soil Analysis: Part 2- Chemical and Microbiological Properties (2nd ed.), A.L. Page (Ed), ASA and SSSA Agronomy Monograph No.9, Madison, pp. 149-157.

Soil Survey Staff., 1993. Soil Survey Manual, USDA Handbook No: 18, Washington D.C.

Soil Survey Staff., 1999. Soil Taxonomy. A Basic of Soil Classification for Making and Interpreting Soil Survey. USDA Handbook No: 18, Washington D.C.

Soil Survey Staff., 2014. Keys to Soil Taxonomy. United States Department of Agriculture. NRCS, USDA p 372.

Thomas, G.W., 1986. "Exchangeable Cations”, In : Methods of Soil Analysis, Part II, Chemical and Microbiological Properties, ASA and SSSA Agronomy Monograph, No.9 (2nded), Madison, pp:159-164.

Tunçay, T., Başkan, O., Bayramin, İ., Dengiz, O., Kılıç, Ş., 2018. Geostatistical approach as a tool for estimation of field capacity and permanent wilting point in semiarid terrestrial ecosystem. Archives of Agronomy and Soil Science, 64 (9); 1240-1253, doi.org/10.1080/03650340.2017.1422081.

Tüzüner, A., 1990. Toprak ve Su Laboratuvarları El Kitabı, T.C. Tarım Orman ve Köyişleri Bakanlığı Köy Hizmetleri Genel Müdürlügü Yayınları, 352 sayfa, Ankara. 